\title{
Renovating Golf Course Fairways with Zoysiagrass Seed
}

\author{
Aaron J. Patton ${ }^{1}$ \\ Department of Agronomy, Purdue University, 915 West State Street, West \\ Lafayette, IN 47907-2054
}

\author{
David W. Williams ${ }^{2}$ \\ Department of Agronomy, University of Kentucky, Room N-222J Agricultural \\ Science Building, Lexington, KY 40546-0091 \\ Zachary J. Reicher ${ }^{2}$ \\ Department of Agronomy, Purdue University, 915 West State Street, West \\ Lafayette, IN 47907-2054
}

Additional index words. Zoysia japonica, MSMA, dithiopyr, glyphosate, herbicide, conversion, interseeding

\begin{abstract}
Zoysiagrass (Zoysia japonica Steud.) requires few inputs and provides high-quality turf in the transition zone, but is expensive to sprig or sod. Establishment by seed is less expensive than vegetative establishment, but little is known about renovation of existing turf to zoysiagrass using seed. Two experiments were performed to determine effects of herbicides and seeding rates on establishment of zoysiagrass in Indiana and Kentucky. In the first experiment, interseeding zoysiagrass into existing perennial ryegrass (Lolium perenne L.) without the use of glyphosate before seeding resulted in $2 \%$ zoysiagrass coverage 120 days after seeding (DAS). In plots receiving glyphosate before seeding, zoysiagrass coverage reached $100 \%$ by 120 DAS. In the second experiment, MSMA + dithiopyr applied 14 days after emergence (DAE) or MSMA applied at 14+28+42 DAE provided the best control of annual grassy weeds and the greatest amount of zoysiagrass establishment. Applying MSMA + dithiopyr 14 DAE provided 7\% less zoysiagrass coverage compared to MSMA applied 14 DAE at one of the four locations. Increasing the seeding rate from $49 \mathrm{~kg} \cdot \mathrm{ha}^{-1}$ to $98 \mathrm{~kg} \cdot \mathrm{ha}^{-1}$ provided $3 \%$ to $11 \%$ more zoysiagrass coverage by the end of the growing season at 3 of 4 locations. Successful zoysiagrass establishment in the transition zone is most dependent on adequate control of existing turf using glyphosate before seeding and applications of MSMA at 14+28+42 DAE, but establishment is only marginally dependent on seeding rates greater than $49 \mathrm{~kg} \cdot \mathrm{ha}^{-1}$. Chemical names used: $N$-(phosphonomethyl) glycine (glyphosate); monosodium methanearsenate (MSMA); $S, S$-dimethyl 2-(difluoromethyl)-4-(2-methylpropyl)-6-(triflurormethyl)-3,5-pyridinedicarbothioate (dithiopyr).
\end{abstract}

Zoysiagrass (Zoysia japonica Steud.) is a warm-season turfgrass well-suited for golf course fairways, tees, and bunker faces in the transition zone of the U.S. Once established, zoysiagrass creates a dense, high-quality turf that is relatively inexpensive to maintain. Zoysiagrass is traditionally established through plugging, sprigging, strip-sodding, or sodding (Portz et al., 1981). However, because of the high cost of vegetative establishment, less well-adapted species such as bermudagrass (Cynodon spp. Rich.) or perennial ryegrass (Lolium perenne L.) are often used instead of zoysiagrass in transition zone fairways. Improved zoysiagrass cultivars established by seed were recently developed and commercially released (NTEP, 2001). Zoysiagrass establishment by seed is desirable because it is less expensive than vegetative establishment.

\footnotetext{
Received for publication 25 Oct. 2003. Accepted for publication 17 Feb. 2004. Purdue University Agricultural Experiment Station journal 17281.The authors thank Judy Santini for help with statistical analysis and the Midwest Regional Turf Foundation for partial support of this project.

${ }^{1}$ Graduate research assistant, to whom correspondence should be sent; e-mail ajpatton@purdue. edu.

${ }^{2}$ Associate professor.
}

was used in their study in spite of suggested seeding rates of 38 to $98 \mathrm{~kg} \mathrm{ha}^{-1}$ (Portz et al., 1981; Landry and Choi, 1995). Additionally, Madison (1966) reported higher seeding rates of cool-season grasses increased seedling number shortly after emergence. Therefore, higher seeding rates may give zoysiagrass seedlings a competitive advantage when interseeding cool-season turf.

Weed control is often necessary after seeding to optimize establishment (Johnson, 1976). Fast-growing weeds will out-compete slow germinating and slow growing zoysiagrass during renovation. Competitive annual grassy weeds such as crabgrass (Digitaria spp.) and goosegrass (Eleusine indica L.) germinate in late spring and early summer and reduce zoysiagrass establishment (Carroll et al., 1996). There are several herbicides labeled for the control of crabgrass and goosegrass in established zoysiagrass, but none are labeled for use on zoysiagrass seedlings. Portz et al. (1981) found the preemergence herbicide siduron [1-(2-methylcyclohexyl)-3-phenylurea] applied before seeding produced the highest zoysiagrass coverage, but two postemergence applications of MSMA plus 2,4-D [(2,4-dichlorophenoxy) acetic acid]/ dicamba (3,6-dichlor-2-methoxybenzoic acid) also provided acceptable zoysiagrass coverage. Siduron can be used on seedling turfgrass to control crabgrass, but it provides poor residual control in the transition zone (Dernoeden, 1984). Dithiopyr, a preemergence herbicide with early postemergence activity, has longer residual activity than siduron and provides better weed control for cool-season turf renovations (Reicher et al., 1999). Preliminary field work showed that MSMA, dithiopyr, and MSMA + dithiopyr are safe on zoysiagrass seedlings 1 week after emergence or later (Hardebeck and Reicher, 2003; Reicher and Hardebeck, 2002b).

We initiated research to determine 1) effect of seeding rate and nonselective herbicides on zoysiagrass establishment when interseeding into perennial ryegrass, and 2) effect of seeding rate and postemergence weed control during zoysiagrass renovation on four golf courses in the transition zone.

\section{Materials and Methods} but may not be successful because of competition from existing grasses (Eggens, 1979). Interseeding creeping bentgrass (Agrostis palustris Huds.) or kentucky bluegrass (Poa pratensis L.) into highly competitive annual bluegrass (Poa annua L.) is only marginally successful (Eggens, 1979; Gaussoin and Branham, 1989; Reicher and Hardebeck, 2002a). Interseeding a species or cultivar into another similar species or cultivar is unsuccessful because the new seedlings have little or no competitive edge over the existing established grass (Kendrick and Danneberger, 2002). However, seeding a warm-season grass into a cool-season grass may be successful because of their distinctly different seasonal growth cycles. Little information exists on interseeding a warm-season grass into an existing stand of a cool-season grass. Zoysiagrass interseeded into perennial ryegrass produced only $5 \%$ coverage after one growing season in Kansas (Zuk and Fry, 2002). However, only one seeding rate $\left(49 \mathrm{~kg} \cdot \mathrm{ha}^{-1}\right)$
Interseeding zoysiagrass into perennial ryegrass. Research was conducted at the W.H. Daniel Turfgrass Research and Diagnostic Center, West Lafayette, Ind. Soil type was a Stark silt loam (fine-silty mixed mesic Aeric Ochraqualfs) with a $\mathrm{pH}$ of 5.9, $224 \mathrm{~kg} \cdot \mathrm{ha}^{-1} \mathrm{P}$, $1044 \mathrm{~kg} \cdot \mathrm{ha}^{-1} \mathrm{~K}$ and $7.3 \%$ organic matter. Experiments were initiated on 23 May 2001, 30 May 2002 and 15 June 2002 on an established perennial ryegrass stand with a mowing height of $1.9 \mathrm{~cm}$. Experimental design was a $2 \times 3$ factorial with two herbicide treatments and three seeding rates. Herbicide treatments were glyphosate before interseeding or no glyphosate. Glyphosate was applied in $815 \mathrm{~L} \cdot \mathrm{ha}^{-1}$ of water with a $1.5-\mathrm{m}$ boom with three flat fan nozzles at $1.7 \mathrm{~kg} \cdot \mathrm{ha}^{-1}$ in 2001 and $5.9 \mathrm{~kg} \cdot \mathrm{ha}^{-1}$ in 2002 to $1.5 \times 1.5-\mathrm{m}$ plots with a $\mathrm{CO}_{2}$ pressurized sprayer at $207 \mathrm{kPa}$. Seeding rates were 49, 98 and $146 \mathrm{~kg} \cdot \mathrm{ha}^{-1}$ pure live seed (PLS) 'Zenith' 
Table 1. Site and management information of the four locations for the seeding rate and herbicide strategy study.

\begin{tabular}{|c|c|c|c|c|}
\hline \multirow[b]{2}{*}{ Site information } & \multicolumn{4}{|c|}{ Location } \\
\hline & Camby, Ind. & Mitchell, Ind. & Evansville, Ind. & Richmond, Ky. \\
\hline Location & driving range tee & 12th fairway & 9th fairway & 16th fairway \\
\hline Mowing & $3 \times /$ week & $2 \times /$ week & $3 \times /$ week & $3 \times /$ week \\
\hline Irrigation & to prevent stress & May 20 to July 1 & to prevent stress & to prevent stress \\
\hline Primary annual grassy weeds & crabgrass & goosegrass and crabgrass & goosegrass and crabgrass & goosegrass \\
\hline $\mathrm{N}$ applied during study & $87 \mathrm{~kg} \cdot \mathrm{ha}^{-1}$ & $87 \mathrm{~kg} \cdot \mathrm{ha}^{-1}$ & $87 \mathrm{~kg} \cdot \mathrm{ha}^{-1}$ & $488 \mathrm{~kg} \cdot \mathrm{ha}^{-1}$ \\
\hline Soil texture & silt loam & silt loam & silt loam & silt loam \\
\hline Soil series & Crosby & Crider & Henshaw & Lowell \\
\hline \multirow[t]{2}{*}{ Soil family } & fine mixed mesic & fine-silty mixed mesic & fine-silty mixed mesic & fine mixed mesic \\
\hline & Aeric Ochraqualfs & Typic Paleudalfs & Typic Fragiaqualfs & Typic Hapludalfs \\
\hline Soil pH & 7.3 & 5.3 & 7.0 & 5.3 \\
\hline Soil $\mathrm{kg} \cdot \mathrm{ha}^{-1} \mathrm{P}$ & 121 & 52 & 95 & 196 \\
\hline Soil kg $\cdot \mathrm{ha}^{-1} \mathrm{~K}$ & 218 & 477 & 221 & 663 \\
\hline Soil \% organic matter & 5.4 & 4.0 & 2.7 & 7.8 \\
\hline Seeding date & 20 May & 20 May & 20 May & 29 May \\
\hline Emergence date ${ }^{z}$ & 8 June & 8 June & 8 June & 11 June \\
\hline Days until emergence & 19 & 19 & 19 & 13 \\
\hline
\end{tabular}

${ }^{\mathrm{z}}$ Emergence was defined as a uniform stand of one-leaf seedlings on each untreated plot.

zoysiagrass. Plots were arranged in a randomized complete-block design with four replications. Plots were core aerified and verticut 6 $\mathrm{mm}$ deep in two directions before seeding and then irrigated to promote germination. Plots were fertilized with urea $(46 \mathrm{~N}-0 \mathrm{P}-0 \mathrm{~K})$ at 49 $\mathrm{kg} \cdot \mathrm{ha}^{-1} \mathrm{~N}$ at seeding and monthly throughout the study. Mowing heights were reduced to $1.3 \mathrm{~cm}$ after seeding and maintained at $1.3 \mathrm{~cm}$ with a reel-type mower for the remainder of the experiment. Quinclorac (3,7-dichloro-8-quinolinecarboxylic acid) was applied $30 \mathrm{~d}$ after seeding (DAS) in both years to control crabgrass, and weed escapes were mechanically removed 60 DAS. Percent zoysiagrass coverage was visually estimated on a $0 \%$ to $100 \%$ linear scale monthly and also determined using a modified grid as

Fig. 1. Geographic location of four golf course sites for seeding rate and herbicide strategy studies.

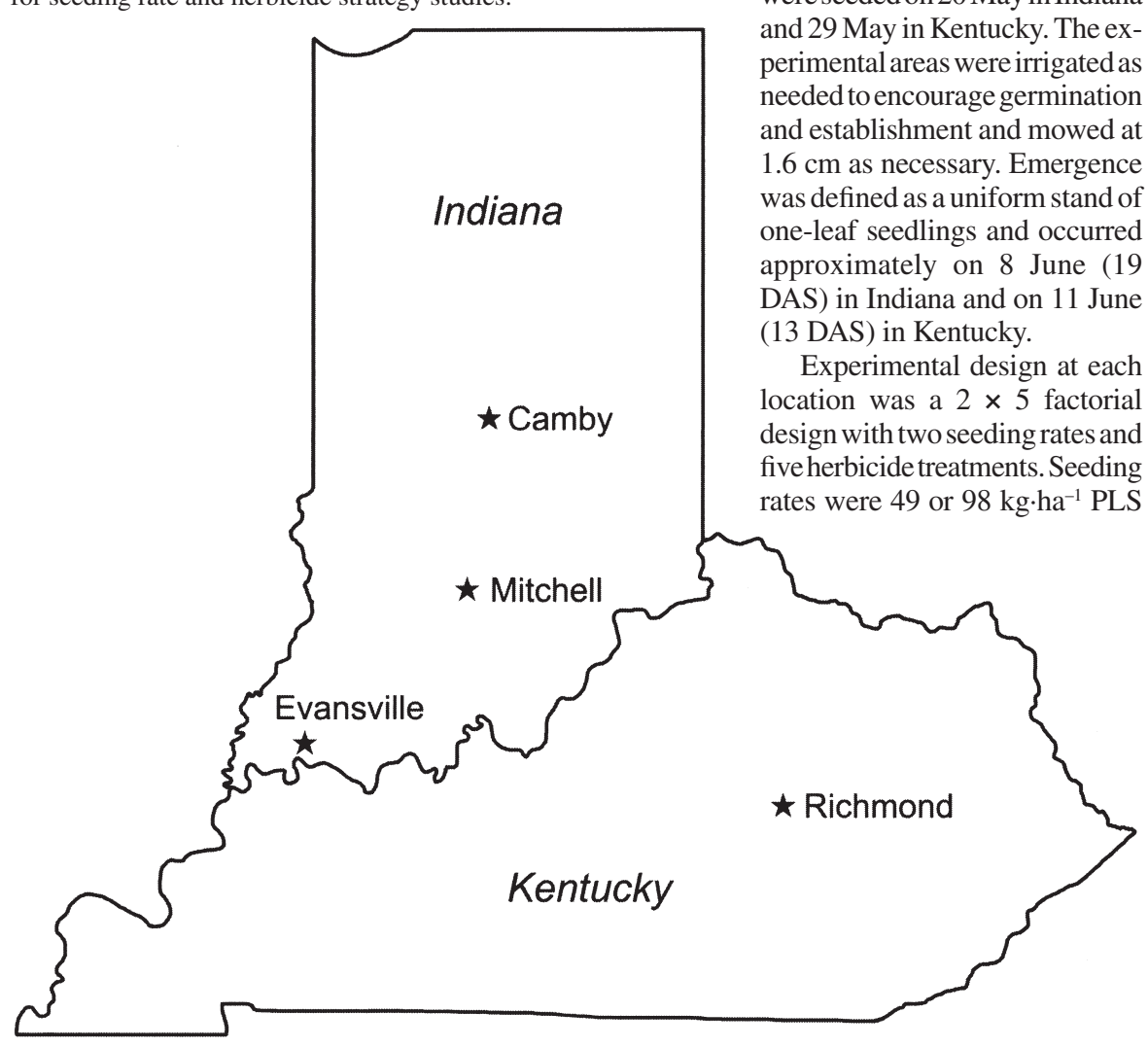

described by Guassion and Branham (1989). A $1.5 \times 1.5$-m PVC frame with an internal filament grid of 81 intersections was placed over each plot. The total number of times that zoysiagrass was present under an intersection was recorded for each plot. Percent coverage using the grid was calculated by dividing the number of times zoysiagrass occurred under a filament intersection by 81 . Data were arcsin transformed before analysis of variance by PROC ANOVA (SAS Institute, 1999-2001) and backtransformed treatment means are presented.

Seeding rate and herbicide strategy. We established experiments in May 2002 at four locations including Camby, Ind.; Mitchell, Ind.; Evansville, Ind.; and Richmond, Ky. (Table 1 and Fig. 1). Glyphosate at $5.9 \mathrm{~kg} \cdot \mathrm{ha}^{-1}$ was applied $7 \mathrm{~d}$ before seeding, and plots were core aerified and verticut $2 \mathrm{~d}$ before seeding. Plots were seeded on 20 May in Indiana and 29 May in Kentucky. The experimental areas were irrigated as needed to encourage germination and establishment and mowed at $1.6 \mathrm{~cm}$ as necessary. Emergence occurred 1 June DAS) in Kentucky. design with two seeding rates and ive herbicide treatments. Seeding rates were 49 or $98 \mathrm{~kg} \cdot \mathrm{ha}^{-1}$ PLS of 'Zenith' zoysiagrass. Herbicide treatments included an untreated check, MSMA at 2.3 $\mathrm{kg} \cdot \mathrm{ha}^{-1}$ applied $14,14+28$, or $14+28+42 \mathrm{~d}$ after emergence (DAE) \pm 1 day, and MSMA at 2.3 $\mathrm{kg} \cdot \mathrm{ha}^{-1}$ plus dithiopyr at $0.56 \mathrm{~kg} \mathrm{ha}^{-1}$ applied $14 \pm 1$ DAE. Herbicides were applied with a $1.5 \mathrm{~m}$ boom with 3 flat fan nozzles in 815 $\mathrm{L} \cdot \mathrm{ha}^{-1}$ of water with a $\mathrm{CO}_{2}$-pressurized sprayer at $207 \mathrm{kPa}$. Plots were arranged in a randomized complete-block design with three replications at each site. Plot size was $3 \times 3 \mathrm{~m}$ in Indiana and $1.5 \times 3$ min Kentucky. Pronamide [3,5-dichloro (N-1,1-dimthyl-2-propynyl)benzaminde] was applied on 2 August in Evansville to kill perennial ryegrass, and carfentrazone [Ethyl $\alpha, 2$-dichloro-5-(4-(difluromethyl)-4,5-dihydro3-methyl-5-oxo-1H-1,2,4-triazol-1-yl)-4-fluorobenzenepropanoate] was applied in Mitchell and Camby on 2 Aug. to kill prostrate spurge (Euphorbia supina Rafin) and white clover (Trifolium repens L.).

Zoysiagrass coverage was visually estimated on a 0 to $100 \%$ linear scale twice monthly and also determined with the modified grid previously described. Since plots were larger in this study, data was collected with the grid in the northwest and southeast corners of each plot to determine zoysiagrass coverage. Percent zoysiagrass using the grid was calculated by dividing the number of times zoysiagrass occurred under a filament intersection by 162 . Weeds in Richmond were mechanically removed after data collection at $56 \mathrm{DAE}$ at request of the golf course superintendent, and data in Richmond were only collected until 100 DAS. Due to the variation in management, locations were not combined for statistical analysis and are discussed separately. Data from five plots in Mitchell and two plots in Evansville were gross outliers, and thus were removed and estimates of coverage were calculated by covariance before analysis. Data were arcsin transformed before analysis of variance by PROC ANOVA (SAS Institute, 1999-2001), and backtransformed treatment means are presented.

\section{Results and Discussion}

Interseeding zoysiagrass into perennial ryegrass. Glyphosate only partially controlled perennial ryegrass in 2001, and zoysiagrass 
Table 2. Effect of seed rate and glyphosate applied before interseeding 'Zenith' zoysiagrass into perennial ryegrass on zoysiagrass coverage in October following seeding dates of 23 May 2001, 30 May 2002, and 15 June 2002.

\begin{tabular}{|c|c|c|c|c|c|c|c|c|c|}
\hline \multirow{3}{*}{$\begin{array}{l}\text { Seeding } \\
\text { rate } \\
\mathrm{kg} \cdot \mathrm{ha}^{-1}\end{array}$} & \multicolumn{3}{|c|}{23 May 2001} & \multicolumn{3}{|c|}{30 May 2002} & \multicolumn{3}{|c|}{5 June 2002} \\
\hline & \multicolumn{9}{|c|}{ Herbicide } \\
\hline & Glyphosate & None & Mean & Glyphosate & None & Mean & Glyphosate & None & Mean \\
\hline & \multicolumn{9}{|c|}{ Backtransformed \% zoysiagrass coverage } \\
\hline 49 & 21 & 1 & 11 & $98 b^{z}$ & $1 \mathrm{a}$ & $50 \mathrm{~b}$ & 44 & 0 & 22 \\
\hline 98 & 29 & 1 & 15 & $100 \mathrm{a}$ & $1 \mathrm{a}$ & $51 \mathrm{a}$ & 74 & 1 & 37 \\
\hline 146 & 37 & 1 & 19 & $100 \mathrm{a}$ & $2 a$ & $51 \mathrm{a}$ & 77 & 0 & 39 \\
\hline Mean & 29 & 1 & & 99 & 1 & & 65 & 0 & \\
\hline \multirow{2}{*}{\multicolumn{10}{|c|}{$\begin{array}{l}\text { Analysis of variance } \\
\text { Source of variation }\end{array}$}} \\
\hline & & & & & & & & & \\
\hline Seed rate $(\mathrm{R})$ & & NS & & & $* *$ & & & NS & \\
\hline Herbicide $(\mathrm{H})$ & & $* *$ & & & $* *$ & & & $* *$ & \\
\hline $\mathrm{R} \times \mathrm{H}$ & & NS & & & $*$ & & & NS & \\
\hline
\end{tabular}

${ }^{2}$ Within columns, means followed by the same letter are not significantly different according to $\mathrm{LSD}_{0.05}$.

NS,*,*** Nonsignificant or significant at $P=0.05$ or 0.01 , respectively.

established in areas with no competition from perennial ryegrass. However, trends in 2001 data were similar to both studies in 2002 where perennial ryegrass was completely killed. As expected, glyphosate treatment had the largest effect in all three studies. Glyphosate applied before seeding allowed 28 to $98 \%$ more zoysiagrass coverage than plots receiving no glyphosate (Table 2). In agreement with Kansas research (Zuk andFry 2002), the most successful turf renovation with seeded zoysiagrass occurs when applying glyphosate before seeding. Zoysiagrass seeded into glyphosate-treated turf provided 34\% more coverage when seeded on 30 May compared to seeding on 15 June (Table 2 ). This is similar to our previous work where delaying seeding zoysiagrass by only two weeks in early summer reduced coverage over $17 \%$ when rated in October (Patton, 2003).

Five percent zoysiagrass coverage was obtained in Kansas when no glyphosate was applied before seeding $49 \mathrm{~kg} \cdot \mathrm{ha}^{-1}$ (Zuk and Fry, 2002). Despite increasing seeding rates up to $146 \mathrm{~kg} \cdot \mathrm{ha}^{-1}$, we achieved a maximum of $2 \%$ coverage when no glyphosate was applied. These results agree with previous research where interseeding a cool-season grass into another existing cool-season grass was marginally successful regardless of seeding rate (Eggens, 1979; Gaussoin and Branham, 1989; Reicher and Hardebeck, 2002a). Therefore, renovation to zoysiagrass by interseeding is not recommended unless glyphosate is applied before seeding.

Seeding rate and herbicide strategy. Camby had the highest crabgrass competition among locations. Applying MSMA 14+28+42 DAE or MSMA + dithiopyr 14DAE provided complete control of crabgrass (Table 3). Applications of MSMA 14 DAE or applications of MSMA $14+28$ DAE resulted in $100 \%$ and $62 \%$ crabgrass coverage, respectively, suggesting significant crabgrass germination occurred after $28 \mathrm{DAE}$. As expected, herbicide treatments that provided effective crabgrass control provided the most zoysiagrass coverage in Camby (Table 4). Applying MSMA + dithiopyr 14 DAE and applying MSMA $14+28+42$ DAE produced $90 \%$ or more zoysiagrass coverage by October. Although seeding rate had no effect on weed cover, seeding $98 \mathrm{~kg} \mathrm{ha}^{-1}$ provided $4 \%$ more zoysiagrass coverage than $48 \mathrm{~kg} \cdot \mathrm{ha}^{-1}$ by the end of the season in Camby, when averaged over all herbicide treatments.
Annual grass competition was also high in Mitchell (Table 3). Applying MSMA 14+28 DAE or $14+28+42$ DAE, or applying MSMA + dithiopyr 14 DAE produced less than $10 \%$ weed coverage. Remaining weeds consisted primarily of goosegrass, which was the most difficult to control weed in our study. Similar to Camby, the poor control from MSMA applied 14 DAE indicated significant summer annual grass germination occurred later in the study. Herbicide treatments that controlled weeds more effectively resulted in higher zoysiagrass coverage (Table 3). Applying MSMA $14+28$ DAE or $14+28+42$ DAE provided $75 \%$ or more coverage, while applying MSMA + dithiopyr 14 DAE resulted in $64 \%$ coverage. The $98 \mathrm{~kg} \cdot \mathrm{ha}^{-1}$ seeding rate produced $5 \%$ less weed coverage than $49 \mathrm{~kg} \cdot \mathrm{ha}^{-1}$ (Table 3 ), but seeding rate had no effect on zoysiagrass coverage (Table 4). Plots in Mitchell had less zoysiagrass coverage than the other three locations. This was most likely due to a local drought that limited growth during July and August.

All herbicide treatments reduced weed coverage in Evansville compared to the untreated control (Table 3). There was limited weed competition in Evansville and hence no difference in weed coverage among herbicide treatments. There was however, enough weed competition that all herbicide treatments increased zoysiagrass coverage by at least $19 \%$ compared to the control (Table 4). Among the four locations, seeding rate had the largest effect in Evansville where seeding $98 \mathrm{~kg} \cdot \mathrm{ha}^{-1}$ provided $11 \%$ more zoysiagrass coverage than $49 \mathrm{~kg} \cdot \mathrm{ha}^{-1}$.

The southernmost location in Richmond had low weed competition and rapid zoysiagrass establishment. Applying MSMA 14+28 DAE or $14+28+42$ DAE provided $14 \%$ less weed coverage compared to the check (Table 3). Applying MSMA $14+28$ was the only treatment to improve zoysiagrass coverage compared to the check (Table 4). Applying MSMA + dithiopyr 14 DAE resulted in lower zoysiagrass coverage than the other herbicide treatments. This likely resulted from applying dithiopyr too soon after germination, damaging emerging seedlings. Germination was more rapid in Richmond than other locations. Emergence was judged to occur $13 \mathrm{~d}$ after seeding in Richmond and $19 \mathrm{~d}$ after seeding in Camby, Mitchell and Evansville. Since a different researcher rated plots in Richmond than in the 3 Indiana sites, application may have been made to slightly less mature zoysiagrass in Richmond, resulting in damage. Preliminary work indicates dithiopyr is safe on zoysiagrass 7 DAE but not at 0 DAE suggesting there is a threshold where zoysiagrass can withstand dithiopyr (Reicher and Hardebeck, 2002b). To avoid risk of zoysiagrass damage by dithiopyr, a more conservative approach may be to apply MSMA at 14+28 DAE and potentially again at 42 DAE if significant grassy weed germination occurs after $28 \mathrm{DAE}$.

Seeding $98 \mathrm{~kg} \cdot \mathrm{ha}^{-1}$ produced $3 \%, 4 \%$, and $11 \%$ more zoysiagrass coverage at Richmond, Camby and Evansville, respectively. Therefore, increasing seeding rate can hasten establishment and reduce the length of time a course is closed during renovation. However, the cost of increasing the seeding rate from 49 to $98 \mathrm{~kg} \cdot \mathrm{ha}^{-1}$ is about $\$ 2,200 \mathrm{ha}^{-1}$. Although seeding rate was a significant treatment effect at three of the four locations, the marginal improvement in zoysia coverage may not be justified.

Zoysiagrass coverage was highest in plots where weeds were effectively controlled. Fifty-six days after emergence, all herbicide treatments except for MSMA applied 14 DAE consistently reduced coverage of annual grassy weeds compared to the check. Since MSMA + dithiopyr inhibited zoysiagrass in Richmond, MSMA applied alone may be a safer alternative. Applications of MSMA should be made 14+28 DAE at a minimum, but applications at $14+28+42$ DAE may be needed if high weed competition exists. Practitioners can monitor weed competition and apply as needed since MSMA is a postemergence herbicide. However, even three applications of MSMA may not effectively control goosegrass. If high goosegrass competition is expected, MSMA + dithiopyr at 14 DAE may be justified because dithiopyr is an effective preemergence goosegrass control (Johnson, 1997).

Successful zoysiagrass establishment in the transition zone depends on adequate glyphosate control of established turf before seeding, and the use of appropriate herbicide applications after emergence to reduce weed competition. Furthermore, zoysiagrass establishment is only marginally dependent on seeding rates greater than $49 \mathrm{~kg} \cdot \mathrm{ha}^{-1}$. With proper establishment procedures and irrigation, our treatments with seeded zoysiagrass produced $>90 \%$ coverage in only one growing season, whereas sprigging 
Table 3. Effect of seed rate in glyphosate treated golf course fairways and herbicide applications after 'Zenith' zoysiagrass seedling emergence on annual grassy weed coverage $56 \mathrm{~d}$ after zoysiagrass emergence.

\begin{tabular}{|c|c|c|c|c|c|c|c|c|c|c|c|c|}
\hline \multirow[b]{3}{*}{ Herbicide treatment } & \multicolumn{3}{|c|}{ Camby, Ind. } & \multicolumn{3}{|c|}{ Mitchell, Ind. } & \multicolumn{3}{|c|}{ Evansville, Ind. } & \multicolumn{3}{|c|}{ Richmond, Ky. } \\
\hline & \multicolumn{12}{|c|}{ Seed rate $\left(\mathrm{kg} \cdot \mathrm{ha}^{-1}\right)$} \\
\hline & 49 & 98 & Mean & 49 & 98 & Mean & 49 & 98 & Mean & 49 & 98 & Mean \\
\hline & \multicolumn{12}{|c|}{ Backtransformed \% grassy weed coverage } \\
\hline Control & $99^{y}$ & 100 & $99 \mathrm{a}^{\mathrm{x}}$ & 94 & 91 & 93 a & 21 & 10 & $15 \mathrm{a}$ & 22 & 9 & $16 \mathrm{a}$ \\
\hline MSMA 14 DAE $^{w}$ & 99 & 100 & $100 \mathrm{a}$ & 43 & 26 & $34 \mathrm{~b}$ & 6 & 5 & $5 \mathrm{~b}$ & 11 & 6 & $8 \mathrm{ab}$ \\
\hline MSMA + Dithiopyr 14 DAE & 0 & 1 & $0 \mathrm{c}$ & 9 & 6 & $8 \mathrm{c}$ & 3 & 2 & $2 \mathrm{~b}$ & 6 & 14 & $10 \mathrm{a}$ \\
\hline MSMA 14+28 DAE & 63 & 61 & $62 \mathrm{~b}$ & 4 & 8 & $6 \mathrm{~cd}$ & 7 & 4 & $5 \mathrm{~b}$ & 2 & 3 & $2 b$ \\
\hline MSMA $14+28+42$ DAE & 0 & 0 & $0 \mathrm{c}$ & 5 & 1 & $3 d$ & 2 & 2 & $2 \mathrm{~b}$ & 3 & 2 & $2 \mathrm{~b}$ \\
\hline Mean & 52 & 52 & & 31 & 26 & & 8 & 5 & & 9 & 7 & \\
\hline \multicolumn{13}{|l|}{$\begin{array}{l}\text { Analysis of variance } \\
\text { Source of variation }\end{array}$} \\
\hline Seed rate $(\mathrm{R})$ & & NS & & & $*$ & & & NS & & & NS & \\
\hline Herbicide $(\mathrm{H})$ & & $* *$ & & & $* *$ & & & $*$ & & & $*$ & \\
\hline $\mathrm{R} \times \mathrm{H}$ & & NS & & & NS & & & NS & & & NS & \\
\hline
\end{tabular}

${ }^{\mathrm{z}}$ Crabgrass (Digitaria spp.) and goosegrass (Eleusine indica L.).

${ }^{\mathrm{y}}$ Means of three replications.

${ }^{x}$ Within columns, means followed by the same letter are not significantly different according to $\mathrm{LSD}_{0.05}$.

${ }^{w}$ Days after emergence.

NS,*,**Nonsignificant or significant at $P=0.05$ or 0.01 , respectively.

Table 4. Effect of seed rate in glyphosate treated golf course fairways and herbicide applications after zoysiagrass seedling emergence on 25 Oct. (2 Sept. for Richmond) 'Zenith' zoysiagrass coverage.

\begin{tabular}{|c|c|c|c|c|c|c|c|c|c|c|c|c|}
\hline \multirow[b]{3}{*}{ Herbicide treatment } & \multicolumn{3}{|c|}{ Camby, Ind. } & \multicolumn{3}{|c|}{ Mitchell, Ind. } & \multicolumn{3}{|c|}{ Evansville, Ind. } & \multicolumn{3}{|c|}{ Richmond, Ky. } \\
\hline & \multicolumn{12}{|c|}{ Seed rate $\left(\mathrm{kg} \cdot \mathrm{ha}^{-1}\right)$} \\
\hline & 49 & 98 & Mean & 49 & 98 & Mean & 49 & 98 & Mean & 49 & 98 & Mean \\
\hline & \multicolumn{12}{|c|}{ Backtransformed \% zoysiagrass coverage } \\
\hline Control & $0^{2}$ & 0 & $0 \mathrm{~d}^{\mathrm{y}}$ & 10 & 10 & $10 \mathrm{c}$ & 57 & 81 & $69 \mathrm{~b}$ & 91 & 96 & $93 \mathrm{bc}$ \\
\hline MSMA 14 DAE $^{x}$ & 0 & 8 & $4 \mathrm{c}$ & 55 & 61 & $58 \mathrm{~b}$ & 81 & 94 & $88 \mathrm{a}$ & 95 & 97 & $96 \mathrm{ab}$ \\
\hline MSMA + Dithiopyr 14 DAE & 86 & 94 & $90 \mathrm{a}$ & 67 & 62 & $64 \mathrm{ab}$ & 81 & 96 & $89 a$ & 87 & 92 & $89 \mathrm{c}$ \\
\hline MSMA $14+28$ DAE & 38 & 34 & $36 \mathrm{~b}$ & 75 & 75 & $75 \mathrm{a}$ & 87 & 90 & $88 \mathrm{a}$ & 99 & 98 & 98 a \\
\hline MSMA $14+28+42$ DAE & 88 & 95 & $92 \mathrm{a}$ & 67 & 86 & $76 \mathrm{a}$ & 87 & 92 & $89 \mathrm{a}$ & 94 & 99 & $96 \mathrm{ab}$ \\
\hline Mean & 42 & 46 & & 55 & 59 & & 79 & 90 & & 93 & 96 & \\
\hline \multicolumn{13}{|l|}{$\begin{array}{l}\text { Analysis of variance } \\
\text { Source of variation }\end{array}$} \\
\hline Seed rate $(\mathrm{R})$ & & $* *$ & & & NS & & & $* *$ & & & $*$ & \\
\hline Herbicide $(\mathrm{H})$ & & $* *$ & & & $* *$ & & & $*$ & & & $*$ & \\
\hline $\mathrm{R} \times \mathrm{H}$ & & NS & & & NS & & & NS & & & NS & \\
\hline
\end{tabular}

${ }^{\mathrm{z}}$ Means of three replications.

${ }^{\mathrm{y}}$ Within columns, means followed by the same letter are not significantly different according to $\mathrm{LSD}_{0.05}$.

${ }^{x}$ Days after emergence.

NS,*,**Nonsignificant or significant at $P=0.05$ or $P=0.01$, respectively.

may take 2 or more years for equivalent coverage (Portzetal., 1981). Our work shows the promise of renovating turf using relatively inexpensive zoysiagrass seed, potentially allowing more golf courses in the transition zone to reap the benefits of zoysiagrass.

\section{Literature Cited}

Carroll, M.J., P.H. Dernoeden, and J.M. Krouse. 1996. Zoysiagrass establishment from sprigs following application of herbicides, nitrogen, and a biostimulator. HortScience 31:972-975.

Dernoeden,P.H. 1984. Management of preemergence herbicides for crabgrass control in transition-zone turf. HortScience 19:443-445.

Eggens, J.L. 1979. The response of some Kentucky bluegrass cultivars to competitive stress from annual bluegrass. Can. J. Plant Sci. 59:11231128 .

Gaussoin, R.E. and B.E. Branham. 1989. Influence of cultural factors on species dominance in a mixed stand of annual bluegrass/creeping bentgrass. Crop. Sci. 29:480-484.

Hardebeck, G.A. and Z.J. Reicher. 2003. Herbicide safety on zoysia seedlings. Purdue Univ., West Lafayette, Ind. 10 June 2003. <http://www.agry. purdue.edu/turf/report/2002/page71.pdf>.

Johnson, B.J. 1976. Renovation of turfgrasses with herbicides. Weed Sci. 24:467-472.

Johnson, B.J. 1997. Reduced herbicides rates for large crabgrass (Digitaria sanguinalis) and goosegrass (Eleusine indica) control in bermudagrass (Cynodon dactylon). Weed Sci. 45:283-287.

Kendrick, D.L. and T.K. Danneberger. 2002. Lack of competitive success of an intraseeded creeping bentgrass cultivar into an established putting green. Crop Sci. 42:1615-1620.

Landry, G. and J.S. Choi. 1995. Effect of zoysiagrass seeding rate on shoot/root development in early establishment. Agron. Abstr. p. 148 (abstr.).

Madison, J.H. 1966. Optimum rates of seeding turfgrasses. Agron. J. 58:441-443.

National Turfgrass Evaluation Program (NTEP). 2001. Mean turfgrass quality ratings of zoysiagrass cultivars. NTEP, Beltsville, Md. 10 June 2003. http://www.ntep.org/data/zg96/zg96_0115f/zg9601ft01a.txt.

Patton,A.J. 2003. Establishment of bermudagrass and zoysiagrass by seed. MS thesis. Purdue Univ.,
West Lafayette, Ind.

Portz, H.L., J.J. Murray, and D.Y. Yeam. 1981. Zoysiagrass (Zoysiajaponica Steud.) establishment by seed. Intl. Turfgrass Soc. Res. J. 4:113-122.

Reicher, Z.J., D.V. Weisenberger, and C.S. Throssell. 1999. Turf safety and effectiveness of dithiopyr and quinclorac for large crabgrass (Digitaria sanguinalis) control in spring-seeded turf. Weed Technol. 13:253-256.

Reicher, Z.J. and G.A. Hardebeck. 2002a. Overseeding strategies for converting golf course fairways to creeping bentgrass. HortScience 37:508-510

Reicher, Z.J. and G.A. Hardebeck. 2002b. Safety of Drive and Dimension on newly seeded bermudagrass and zoysiagrass. Purdue Univ., West Lafayette, Ind. 10 June 2003. <http://www.agry. purdue.edu/turf/report/2001/page59-65.pdf>.

SAS Institute. 1999-2001. Software release 8.02. SAS Inst., Cary, N.C.

Zuk, A.J. and J.D. Fry. 2002. Factors affecting establishment of seeded zoysiagrass in perennial ryegrass turf. 2002 Turfgrass Res. Rpt. Kan. State Univ. 